\title{
Some operations of electric power supply system in Benin City area of Nigeria \\ A. O. Odior ${ }^{1 *}$, F. A. Oyawale ${ }^{2}$ and G.C. Ovuworie ${ }^{3}$ \\ ${ }^{1,3}$ Department of Production Engineering, University of Benin, Nigeria. \\ ${ }^{2}$ Department of Industrial and Production Engineering, University of Ibadan, Nigeria. \\ *E-mail: waddnis@yahoo.com
}

\begin{abstract}
The Power Holding Company of Nigeria (PHCN) is responsible for generating, transmitting, distributing and selling electric power to the various consumers throughout the country. The paper presents the results of an investigation conducted on some of the operations of Power Holding Company of Nigeria (PHCN) to determine some of the major factors affecting the availability of power supply to consumers in Benin City area of Nigeria. The average number of operating transformers in various substations and their percentage loadings were also studied. It was discovered that the average power supply to Government Reservation Area (GRA) was more regular and stable than that of Siluko area of Benin City.
\end{abstract}

Keywords: Electric Power, Major Factors, Operating Transformers, Percentage Loading.

\section{INTRODUCTION}

Electric power supply is the most important commodity for national development. With electrical energy the people are empowered to work from the domestic level and the cottage industries, through the small-scale and medium industries to employment in the large-scale manufacturing complexes. In these days, depriving people of electric power is tantamount to castration. According to Musa (2007). electric power generation may be through one of the following sources of energy: coal, oil or natural gas , hydro power (water turbine), nuclear power (steam turbine), solar-wind or water-wave turbine, solar thermal generator, solar voltaic generator. Coal, oil, gas and hydro power are abundant in Nigeria. Presently Nigeria mostly employs gas-fired and hydroelectric turbines for bulk generation, oil being too expensive and coal-fired stations having gone moribund, Musa (2007). Maximum power consumption or peak demand depends on the population and industrialization of a country. If the maximum supply meets the peak demand, there is a surplus otherwise there is a shortfall. Supply, demand and losses are related by the following equation, Musa (2007):

Supply - Demand $=$ Supply - Actual needs Losses $=$ Surplus, and

Losses $=$ Heat losses + Wastages + Diversions

However, in Nigeria, the power supply system is run with a shortfall where demand exceeds supply.

The Power Holding Company of Nigeria (PHCN) is responsible for generating, transmitting, distributing and selling electric power to the various consumers throughout the country. A major objective of PHCN, naturally has been to provide regular and an uninterrupted power supply to the consumers of electricity nationwide. However, Benin City, one of PHCN's main distribution areas in Edo State has suffered a great deal of irregular power supply in the last few decades. A number of authors have studied power supply systems and various aspects of their operations (Lequeux, 1980; Kurzyn, 1981; Becker, 1981; Rahman, 1981). However, very few have investigated and documented in learned journals the counterpart of the system in Nigeria. Manafe (1979) studied the establishment and the growth of electricity in Nigeria. He found that the various stage of electricity development in Nigeria had been under the following controlling Authorities: The Public Works Department (PWD), The Nigeria Electricity Supply Co-operation (NESCO), The African Timber and Plywood Limited (AT\&P), The Electricity Cooperation of Nigeria (ECN), The Niger Dams Authority (NDA) and the National Electric Power Authority (NEPA).

The capacity in Kilowatt generated by each of the generating units in various parts of the country has also been studied (Oyeyele, 1987). That work also examined the Nigerian electricity market and found that the annual growth rate of electricity sales averaged about 18 percent in the period of 1950/52 to $1976 / 77$. It concluded, in part, that Nigeria still has a low electricity consumption of $60 \mathrm{KWH} /$ Capita (1979 figures), which is less than 1 percent of that of industrialized countries. It was discovered that developing countries like Liberia, Ivory Coast and 
Guinea have per capital electricity of about ten times, four times and two times respectively than that of Nigeria. The work, however, pointed out that the low consumption capita in Nigeria is due to the fact that over 80 percent of the population normally reside in the rural areas where they have no access to electricity as well as low level of industrialization. The Public Relations Department (PRD) of PHCN has reported that there was a rapid expansion in electrical energy transmission in the period $1960-1985$. The solar and wind energy resource in Nigeria has also been studied (Sambo, 1987). The author found that the annual mean of solar energy received in Nigeria is $2,300 \mathrm{Kwh}$ per meter squared and global radiation is as high as $24 \mathrm{MJ}$ per meter squared per day due to its good geographical location between latitude 4 degree and 14 degree north of the equator. Anazia, in 1990 considered the preventive maintenance and diagnostic testing intervals for electrical equipment in a cement factory in Nigeria.

Nigeria's public power company-Power Holding Company of Nigeria has an installed generating capacity of about $6 \mathrm{GW}$ but actual available output is less than $2.5 \mathrm{GW}$. Power black-out is frequent. New generation capacity-build-up under the National

Integrated Power Project (NIPP) would result in more than $10 \mathrm{GW}$ by 2010. Available public capacity is supplemented by private captive generation serving industrial clusters and specific companies in the Cement, Steel and Oil \& Gas sectors of the economy. A set of newly licensed independent power producers (IPP) would add more than $10 \mathrm{GW}$ if all come on stream before 2010-2012, (Olivia, 2008).

On the whole, the literature on power distribution in Nigeria is rather scanty and to the best of authors' knowledge, it appears that very little work, if any, has been done in assessing the reliability of power supply. In particular, we could find no published work that dealt with the factors responsible for the reliability of power supply to consumers in Benin City; the present work which is an attempt to fill this gap is a follow up on an earlier one (Odior, 2005).

Major feeders and injection substations in Benin City: There are essentially five major feeders from transmission to all the injection substations in Benin City. These feeders transmit electric power supply to the various injection substations. The location and capacity of each of these feeders as well as the attached injection substations are presented in Table 1.

Table 1: Major Feeders and Attached Injection Substations

\begin{tabular}{|l|l|l|}
\hline Location & Capacity & Attached Injection Substation \\
\hline Benin Feeder I & $30 \mathrm{MVA}$ & G.R.A. and Nekpenekpen \\
\hline Benin Feeder II & $30 \mathrm{MVA}$ & $\begin{array}{l}\text { Guinness, Federal Housing Estate, Ugbowo, UNIBEN and } \\
\text { Okada Village. }\end{array}$ \\
\hline Sapele/ Koko Feeder & $30 \mathrm{MVA}$ & Ologbo, Oghare and Koko. \\
\hline Etete feeder & $60 \mathrm{MVA}$ & Etete I and Etete II. \\
\hline Ikpoba Dam Feeder & $60 \mathrm{MVA}$ & Siluko and Ikpoba Dam. \\
\hline
\end{tabular}

The Power Holding Company of Nigeria (PHCN) formerly known as National Electric Power Authority (NEPA) has established and is implementing guidelines for the percentage loading of any power transformer based on the following criteria: the load reading on the power transformer, and the rating in ampere on the secondary side of the transformer. The rating in ampere on the secondary side of the transformers commonly used in power distribution are typified by Table 2 and the estimation of the percentage loading for each period depends on the rating in ampere on the secondary side of the particular transformer concerned.

Table 2: Rating of Injection Substations.

\begin{tabular}{|l|l|l|l|}
\hline $\begin{array}{l}\text { Injection } \\
\text { Substation }\end{array}$ & $\begin{array}{l}\text { Capacity of Transformer } \\
\text { MVA }\end{array}$ & $\begin{array}{l}\text { Voltage } \\
\text { KV }\end{array}$ & $\begin{array}{l}\text { Transformer's Rating on the Secondary } \\
\text { Side (AMPS) }\end{array}$ \\
\hline GRA S/S TXI & 7.5 & $33 / 6.6$ & 650 \\
\hline SILUKO S/S TXI & 7.5 & $33 / 11$ & 394 \\
\hline SILUKO S/S TXII & 7.5 & $33 / 11$ & 394 \\
\hline
\end{tabular}

Electric power outages : Electric power outages occur frequently in Benin City and some of the factors responsible for such outages were also studied for a period of five months for Siluko and GRA injection substations. A summary of the results is presented in Table 3. It is observed that GRA is more under control than the Siluko injection substation. 
Am. J. Sci. Ind. Res., 2010, 1(3): 636-642

Table 3: Major Factors for Electric Power Outages

\begin{tabular}{|l|l|l|l|l|}
\hline \multirow{2}{*}{ Factors } & \multicolumn{2}{|l|}{ Numbers of Outages } & \multirow{2}{*}{ Total } & \multirow{2}{*}{ Percentage } \\
\cline { 2 - 3 } & SILUKO & GRA & & \\
\hline Man - Made & 64 & 28 & 92 & 40.9 \\
\hline Earth fault & 40 & 15 & 55 & 24.4 \\
\hline Over current & 19 & 15 & 34 & 15.1 \\
\hline Natural fault & 15 & 12 & 27 & 12.0 \\
\hline Transient fault & 12 & 5 & 17 & 7.6 \\
\hline
\end{tabular}

Table 4: Mean Daily Peak Load Readings for GRA Injection Substation

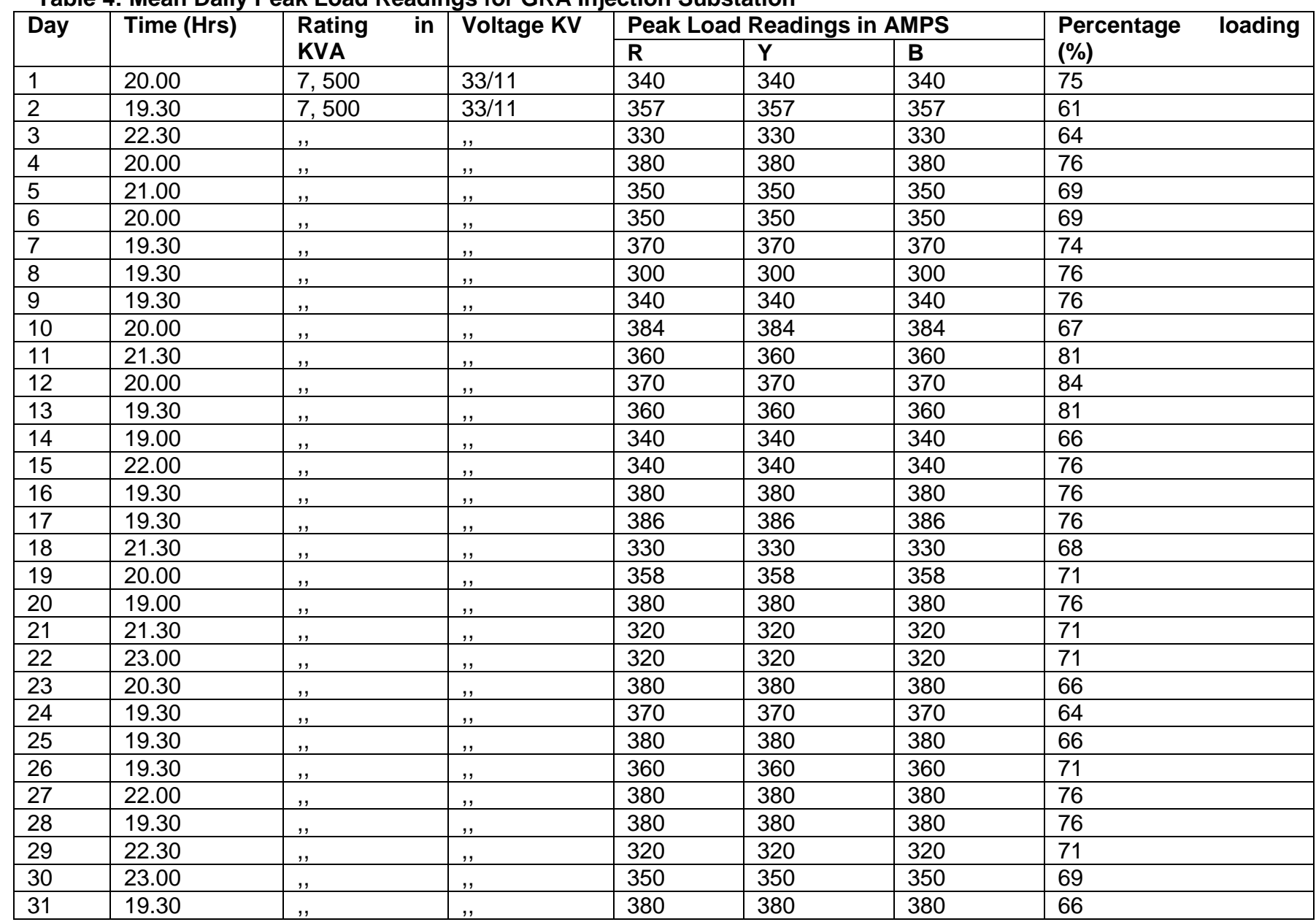


Table 5: Mean Daily Peak Load Readings for Siluko Injection Substation (T x 1)

\begin{tabular}{|c|c|c|c|c|c|c|c|}
\hline \multirow[t]{2}{*}{ Day } & \multirow[t]{2}{*}{ Time (Hrs) } & \multirow{2}{*}{$\begin{array}{l}\text { Rating in } \\
\text { KVA }\end{array}$} & \multirow[t]{2}{*}{ Voltage KV } & \multicolumn{3}{|c|}{ Peak Load Readings in AMPS } & \multirow{2}{*}{$\begin{array}{l}\text { Percentage } \\
\text { loading (\%) }\end{array}$} \\
\hline & & & & $\mathbf{R}$ & $\mathbf{Y}$ & B & \\
\hline 1 & 21.00 & 7,500 & $33 / 11$ & 310 & 310 & 310 & 79 \\
\hline 2 & 20.30 & 7,500 & $33 / 11$ & 350 & 350 & 350 & 89 \\
\hline 3 & 21.30 & , & , & 380 & 380 & 380 & 99 \\
\hline 4 & 20.30 & , & , & 320 & 320 & 320 & 80 \\
\hline 5 & 22.30 & , & , & 300 & 300 & 300 & 76 \\
\hline 6 & 20.00 & , & , & 350 & 350 & 350 & 89 \\
\hline 7 & 22.00 & , & , & 340 & 340 & 340 & 86 \\
\hline 8 & 20.00 & , & , & 340 & 340 & 340 & 86 \\
\hline 9 & 20.30 & , & , & 350 & 350 & 350 & 89 \\
\hline 10 & 20.30 & , & , & 350 & 350 & 350 & 89 \\
\hline 11 & 19.30 & , & , & 380 & 380 & 380 & 96 \\
\hline 12 & 20.00 & , &, & 370 & 370 & 370 & 94 \\
\hline 13 & 19.30 & , & , & 350 & 350 & 350 & 89 \\
\hline 14 & 22.30 & , & , & 310 & 310 & 310 & 79 \\
\hline 15 & 19.30 & , & , & 350 & 350 & 350 & 89 \\
\hline 16 & 19.00 & , & , & 380 & 380 & 380 & 96 \\
\hline 17 & 20.30 & , & , & 390 & 390 & 390 & 97 \\
\hline 18 & 19.30 & , & , & 380 & 380 & 380 & 96 \\
\hline 19 & 19.30 & , & , & 360 & 360 & 360 & 91 \\
\hline 20 & 19.30 & , &, & 90 & 90 & 90 & 23 \\
\hline 21 & 19.00 & , & , & 350 & 350 & 350 & 89 \\
\hline 22 & 19.30 & , & , & 370 & 370 & 370 & 94 \\
\hline 23 & 19.30 & , & , & 370 & 370 & 370 & 94 \\
\hline 24 & 20.00 & , & , & 380 & 380 & 380 & 96 \\
\hline 25 & 19.30 & , & , & 350 & 350 & 350 & 89 \\
\hline 26 & 21.30 & , & , & 350 & 350 & 350 & 89 \\
\hline 27 & 20.00 & , &, & 350 & 350 & 350 & 89 \\
\hline 28 & 20.00 & , & , & 370 & 370 & 370 & 94 \\
\hline 29 & 20.00 & , & , & 360 & 360 & 360 & 94 \\
\hline 30 & 19.00 &, &, & 90 & 90 & 90 & 23 \\
\hline 31 & 20.00 &, & , & 270 & 270 & 270 & 61 \\
\hline
\end{tabular}

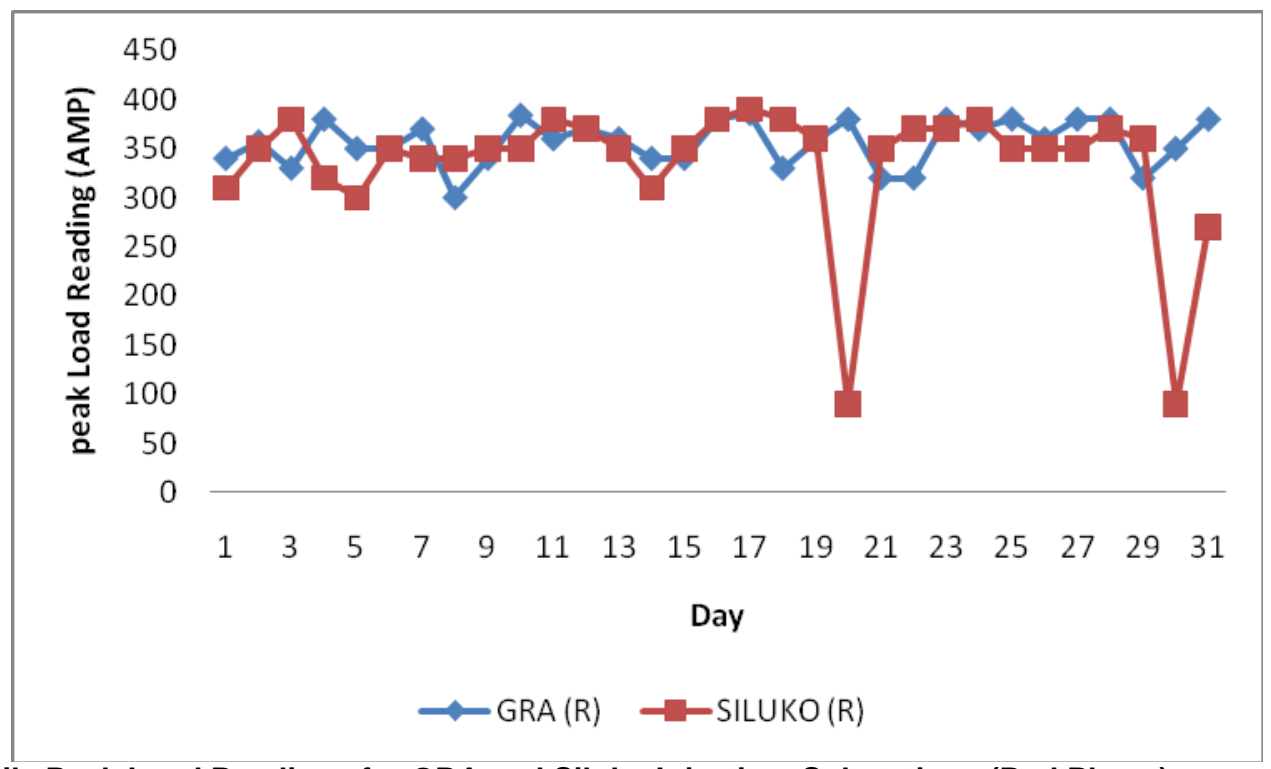

Fig. 1: Mean Daily Peak Load Readings for GRA and Siluko Injection Substations (Red Phase). 
Am. J. Sci. Ind. Res., 2010, 1(3): 636-642

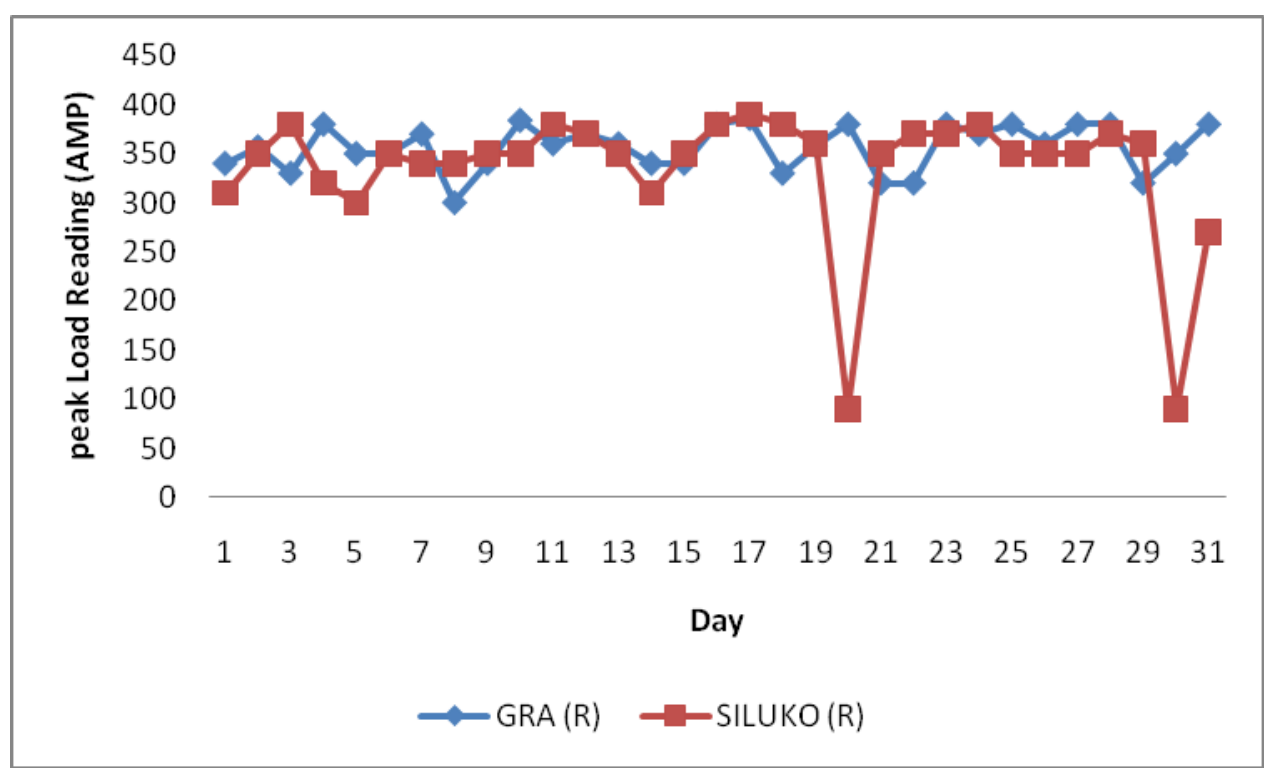

Fig. 2: Mean Daily Peak Load Readings for GRA and Siluko Injection Substations (Yellow Phase).

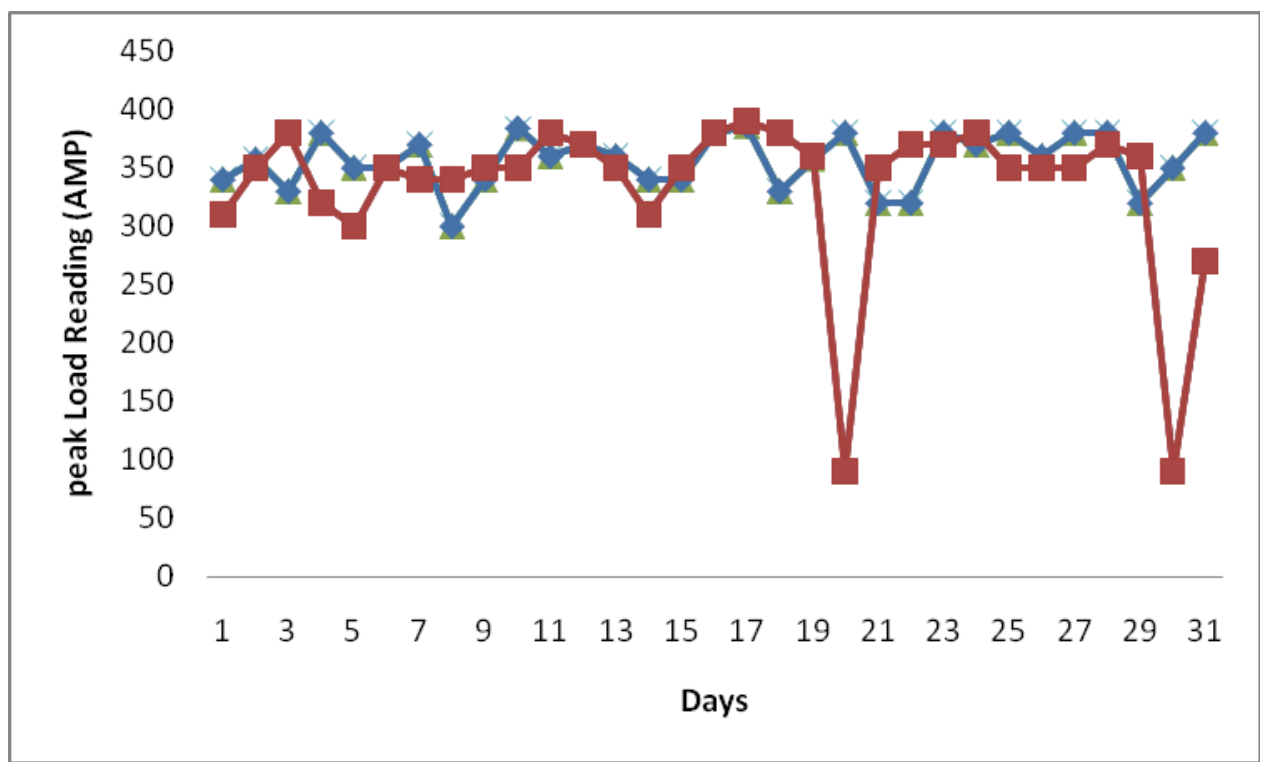

Fig. 3: Mean Daily Peak Load Readings for GRA and Siluko Injection Substations (Blue Phase). 
Am. J. Sci. Ind. Res., 2010, 1(3): 636-642

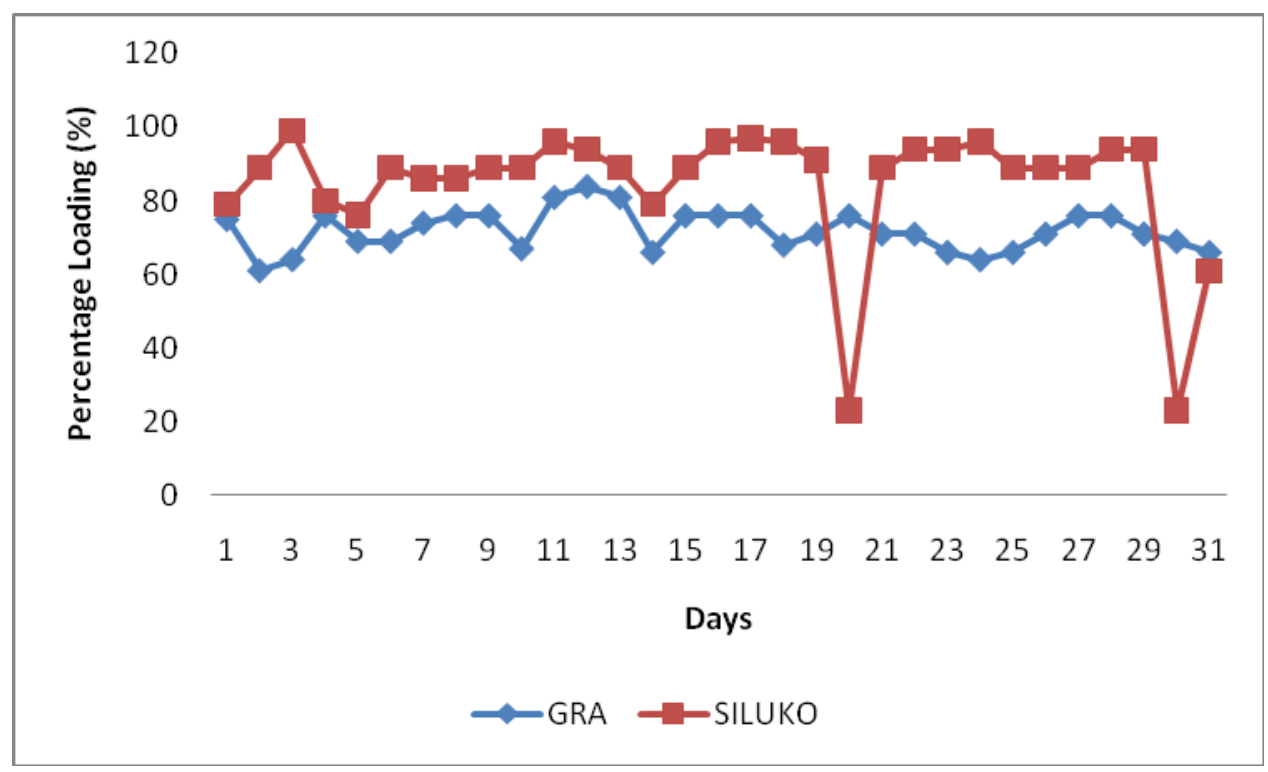

Fig. 4: Mean Percentage Loading

\section{DISCUSSION}

Electric power outages were found to be very frequent in Benin City area of Nigeria and were due to various factors among which are the following: Planned outages which were normally arranged to permit planned maintenance, repair or modification work on in - service equipment and also to enable new equipment to be installed and put into service. Automatic or forced outages are outages caused by different types of inadvertent or unintentional faults in the power supply system. Such faults were found to occur fairly frequently due to storm, lightening, strike action, contractors excavating $\mathrm{PHCN}$ underground cables, vehicles hitting PHCN poles and overhead circuits, earth - faults, and human errors. Emergency outages which are such outages that are neither planned nor automatic. Emergency actions leading to outages, such as load shedding, were sometimes embarked upon in order to save the equipment or system from imminent danger or failure. At a high winding temperature of about $78^{\circ} \mathrm{C}$, the transformer trips off automatically to prevent transformer's explosion. Accordingly, whenever the need arose, load shedding was embarked upon to reduce the load, and hence, the temperature, so as to save the life of the transformer.

\section{CONCLUSION}

The perennial problem of electric power supply in Nigeria has adversely affected every sector of the nation economy. The study has identified and discussed some of the factors that are responsible for inadequate and irregular supply of electric power in the Benin City area of Nigeria. It was found that most of the major factors affecting the availability of power supply could be grouped into two major classes. The first consists of those arising from policy actions, which are deliberate in nature and they are usually taken to safeguard the equipment. They include such actions that are taken during emergency outages, planned or per-arranged outages as well as loadshedding. On the other hand, the other class includes those arising from forces external to the system, and they include over- current, earth fault, high peak load, as well as forced or automatic outages. However, some of the latter may lead to the former.

\section{REFERENCES}

Anazia, C.O. (1990). Preventive Maintenance and Diagnostic Testing Intervals for Electrical Equipment in a Cement Factory. Journal of the Nigeria Institute of Industrial Engineer, Vol 2, No. 1.

Becker, M. (1981). Comparison of Heat Transfer Fluids For Use in Solar Thermal Power Stations. Electric Power Systems Research, Vo1 3, Nos. 3 \& 4.

Kurzyn, M. (1981). Hierarchical Static State Estimation in a Large Scale Electric Power Systems. Estimation Error Analysis. Electric Power Systems Research, Vol. 4, No. 1. 
Lequeux, P. (1980). Autonomous Power Generation in Development Countries. Electrical Power System Research, Vo1.3, Nos. 3\& 4.

Manafa, M.N.A. Electricity Development in Nigeria (1896 1972), Raheem publishers, Lagos, 1979.

Musa D. A. (2007). The Economics of Electric Power Supply In Nigeria. http://www.gamji.com/article9000/NEWS9075.htm. Retrieved on $27^{\text {th }}$. September, 2010.

Odior, A.O. (2005). "Some Major Factors Affecting the Availability of Power Supply to Consumers in Benin City in Recent Times". The Nigerian Journal of Research and Production. Vol. 7, No. 2. pp. 76 - 92.

Olivia P. (2008). Nigeria: Electric Power Sector Report 2008. Olivia Phillip International Consulting Limited. http://www.marketresearch.com/product/display.asp?pr oductid. Retrieved on $27^{\text {th }}$. September, 2010.

Oyeyele, D. (1987). NEPA - A Force in Social and Industrial Development in Nigeria. Lecture presented at the Nigerian Institutes of International Affairs, Victoria Island, Lagos.

Public Relations Department (PRD), (1989). NEPA. Development of Electricity Industry in Nigeria (1960 1985), Private Communication. (Vester Dick, 5 Ojuelegbe Lane, Surulere, Lagos).

Rahman, S. (1981). Power System Operations Scheduling Using Separable Progammin Electric power Systems Research, Vol. 2. No. 4.

Sambo, A.S. (1987). Wind Energy Assisted Solar Electricity Generating Schemes for the Rural Areas of Nigeria. Large Scale Systems in Developing Countries. Vol. 1 (Ovuworie, G.C., Asalor, A.O. and Onibere, E.A. Eds). Joja Publishers Ltd. 